«Ми не можемо розв'язати проблему тим же засобом мислення, за допомогою якого вона з'явилася»

Конотоп Олена Сергіївна, кандидат педагогічних наук, доцент, доцент кафедри мов і методики їх викладання, Національний університет «Чернігівський колегіум» імені Т. Г. Шевченка, o.s.konotop@gmail.com

\title{
МАСОВІ ВІДКРИТІ ОНЛАЙН-КУРСИ ДЛЯ ФОРМУВАННЯ І РОЗВИТКУ КРИТИЧНОГО МИСЛЕННЯ СТУДЕНТІВ ЯК ОСНОВИ ФОРМУВАННЯ ІНШОМОВНОӦ НАВЧАЛЬНО-СТРАТЕГІЧНОї КОМПЕТЕНТНОСТІ
}

Формування критичного мислення набуває особливої актуальності і важливості, оскільки соціальний та технічний прогрес висуває до особистості вимогу вміти швидко адаптуватися до сучасних умов функціонування суспільства, бути здатною до змін і самовдосконалення, знаходити шляхи розв'язання соціальних і прооресійних завдань у нетипових ситуаціях. Інтенсивні процеси глобалізації й інформатизації вимагають від сучасного студента закладу вищої освіти нового типу мислення, яким, як ми вважаємо, іє критичне мислення. Сьогодні формування критичного мислення набуває особливої актуальності і важливості, оскільки соціальний та технічний прогрес висуває до особистості вимогу вміти швидко адаптуватися до сучасних умов фрункціонування суспільства, бути здатною до змін і самовдосконалення, знаходити шляхи розв'язання соціальних і профресійних завдань у нетипових ситуаціях. У сучасному освітньому просторі критичне мислення є основою навчальної діяльності. Результати зрізів критичного мислення студентів свідчать про його середні та низькі показники. Навички критичного мислення спостерігаються в студентів зазвичай ситуативно і не мають системності: більшість молодих людей не можуть пояснити, чому в деяких випадках їм вдається критично осмислити певне явище, а в інших вони сприймають фракти у готовому вигляді, не піддаючи їх критичному аналізу; не усвідомлюють сутності критичного мислення та механізму його здійснення; термін «критичне мислення» переважно асоціюється у них із критикою, що спрямована на знаходження негативних аспектів певних явищ та засудження того, що не відповідає прийнятим у певному середовищі поглядам. Вважаємо, що ефрективним засобом фрормування критичного мислення студентів можуть стати масові відкриті онлайн курси.

Ключові слова: критичне мислення, кліпове мислення, масові відкриті онлайн-курси, студенти закладів вищої освіти.
Конотоп Елена Сергеевна, кандидат педагогических наук, доцент, доцент кафедры языков и методики их преподавания, Национальний университет «Черниговский колегиум» имени Т. Г. Шевченко, o.s.konotop@gmail.com

МАССОВЫЕ ОТКРЫТЫЕ ОНЛАЙН-КУРСЫ ДЛЯ
ФОРМИРОВАНИЯ И РАЗВИТИЯ КРИТИЧЕСКОГО МЫШЛЕНИЯ
СТУДЕНТОВ КАК ОСНОВЫ ФОРМИРОВАНИЯ ИНОЯЗЫЧНОЙ
УЧЕБНО-СТРАТЕГИЧЕСКОЙ КОМПЕТЕНТНОСТИ

Формирования критического мышления приобретает особую актуальность и важность, поскольку социальный и технический прогресс предъявляет к личности требование уметь быстро адаптироваться к современным условиям фуннционирования общества, быть способной к изменениям и самосовершенствованию, находить пути решения социальных и профрессиональных задач в нетипичных ситуациях. Интенсивные процессы глобализации и инфрорматизации требуют от современного студента высших учебных заведений нового типа мышления, которым, как мы считаем, является критическое мышление. Сегодня формирование критического мышления приобретает особую актуальность и важность, поскольку социальный и технический прогресс предъявляет к личности требование уметь быстро адаптироваться к современным условиям функционирования общества, быть способной к изменениям и самосовершенствованию, находить пути решения социальных и профрессиональных задач в нетипичных ситуациях. В современном образовательном пространстве критическое мышление является основой учебной деятельности. Результаты срезов критического мышления студентов свидетельствует о его средних и низких показателях. Навыки критического мышления наблюдаются у студентов обычно ситуативно и не имеют системности: большинство молодых людей не могут объяснить, почему в отдельных случаях им удается критически осмыслить определенное явление, а в других они воспринимают фракты в готовом виде, не подвергая их критическому анализу; не осознают сущности критического мышления и механизма его осуществления; термин "критическое мышление» в основном ассоциируется у них с критикой, направленной на нахождение негативных аспектов определенных явлений и осуждения того, что не соответствует принятым в определенной среде взглядам. Считаем, что эфффективным средством формирования критического мышления студентов могут стать массовые открытые онлайн курсы.

Ключевые слова: критическое мышление, клиповое мышление, массовые открытые онлайн-курсы, студенты высших учебных заведений. 
Konotop, Olena,

$\mathrm{PhD}$ in Pedagogic Sciences

Associate Professor of the Department of Languages and Methods of Teaching

T.H. Shevchenko National University «Chernihiv Colehium» o.s.konotop@gmail.com

\section{MASS OPEN ONLINE COURSES FOR STUDENT'S} CRITICAL THINKING FORMATION AND DEVELOPMENT AS THE BASIS FOR STRATEGIC COMPETENCE

The formation of critical thinking becomes especially relevant and important, because social and technological progress requires the individual to be able to adapt quickly to modern conditions of society, to change and self-improve, to find solutions to social and professional problems in typical situations. Intensive processes of globalization and informatization require a new type of thinking from a modern university student, which, in our opinion, is critical thinking. Today, the formation of critical thinking becomes especially relevant and important, as social and technological progress requires the individual to be able to quickly adapt to modern conditions of society, to be able to change and self-improvement, to find solutions to social and professional problems in atypical situations. In the modern educational space, critical thinking is the basis of educational activities. The results of sections of critical thinking of students indicate its average and low performance. Critical thinking skills are usually situational in students and lack systematicity: most young people cannot explain why they can critically comprehend a phenomenon in some cases, while in others they perceive facts in a ready-made form without subjecting them to critical analysis; do not realize the essence of critical thinking and the mechanism of its implementation; the term "critical thinking" is mostly associated with criticism, which is aimed at finding the negative aspects of certain phenomena and condemning what does not correspond to the views adopted in a particular environment. We believe that mass open online courses can be an effective means of forming students' critical thinking.

Key words: critical thinking, clip thinking, mass open online courses, students of higher education institutions.

Постановка проблеми. У добу стрімкого розвитку всіх сфер суспільного життя важливим стає не стільки сприйняття інформації, скільки її якісне засвоєння й опрацювання. Сучасні дослідження роблять акцент на важливості формування в майбутніх фахівців когнітивних навичок вищого порядку: оригінальність і вільність ідей; стратегій навчання та активного навчання - здатності ставити цілі, відповідні питання, отримувати зворотний зв'язок, коли людина навчається і застосовувати ці знання в різних контекстах, - також посідає особливе місце в навичках, які знадобляться за прогнозами науковців для працевлаштування майбутнім фахівцям до 2030 року (Jobs in 2030 , с. 44 , с. 49 , с. 62 , с. 65 ). Серед переліку найважливіших навичок у перспективі на 2030 р. найбільший попит в українських роботодавців матиме емоційний інтелект, уміння працювати в команді, когнітивні навички, критичне і стратегічне мислення (Jobs in 2030, c. 15).
Сьогодні формування критичного мислення набуває особливої актуальності і важливості, оскільки соціальний та технічний прогрес висуває до особистості вимогу швидко адаптуватися до сучасних умов функціонування суспільства, бути здатною до змін і самовдосконалення, знаходити шляхи розв'язання соціальних і професійних завдань у нетипових ситуаціях. Всесвітній економічний форум у Давосі The World Economic Forum (https://www.weforum.org) уклав перелік навичок, які $€$ необхідними для здійснення успішної кар'єри майбутньому фахівцю. Результати досліджень The World Economic Forum засвідчили зростання ролі критичного мислення в сучасному світі: 4-те місце (навички для 2015 р.), 2-ге місце (навички, які будуть важливими у 2020 р.), у 2030 році - 4-те місце в рейтингу важливості навичок XXI століття. Некомерційна організація США «Партнерство для навчання 21-го століття» (The Partnership For 21st Century Learning) розробила модель ключових компетентностей, у яку входить критичне мислення; ця ж організація представила модель ключових компетентностей з чотирьох більш широких категорій (Модель 4К), однією з ключових якої є також критичне мислення (The Partnership).

Удосконалення сучасної системи навчання іноземних мов (IM) передбачає не лише застосування новітніх методів і підходів, й а розробку та впровадження до освітнього процесу ефективних стратегій, зорієнтованих на активну роботу студентів, створення умов для їх творчого розвитку, самостійності й організованості впродовж усього життя. Вважаємо, що важливою умовою для успішної іншомовної практичної підготовки студентів є сформованість іншомовної навчально-стратегічної компетентності (НСтК), яка допоможе її ефективно реалізувати і дасть змогу бути конкурентноспроможним на сучасному ринку праці. Ефективно сформувати іншомовну НСтК у студентів можливо лише на основі стратегічного і критичного мислення (Конотоп, 2020, с. 345). Усе це зумовлює актуальність проблеми пошуку шляхів забезпечення належного розвитку критичного мислення у студентів вітчизняних ЗВО і засвідчує необхідність спеціально організованої діяльності з формування критичного мислення сучасного фахівця. Розв'язання означеної проблеми є нагальною потребою сучасної вищої освіти.

Метою статті $\epsilon$ здійснити огляд масових відкритих онлайн-курсів (МВОК) для формування і розвитку критичного мислення студентів 3ВО.

Аналіз останніх досліджень і публікацій. Технологія розвитку критичного мислення була розроблена наприкінці XX ст. в США К. Мередіт, Дж. Стіл, Ч. Темпл та ін. Важливий внесок у до- 
слідження критичного мислення зроблено в роботах Т. Воропай, Д. Клустер, М. Ліпман, Р. Пауль, О. Пометун, С. Полат, Дж. Стіл, Ч. Темпл, С. Терно, О. Тягло, М. Чошанов, Д. Халперн та ін. Поняття «критичне мислення» в науковій і методичній літературі почало використовуватися з 1956 року, коли Б. Блум розробив таксономію мислення, де було визначено, які операції на кожному рівні мислення може здійснити мозок людини. Услід за С. Терно критичним мисленням вважаємо наукове мислення, суть якого полягає в ухваленні ретельно обміркованих та зважених рішень стосовно довіри до будь-якого твердження: чи мусимо ми його сприйняти, чи відкинути або відкласти, а також ступінь упевненості, з яким ми це робимо (Терно, 2009, с. 6).

Виклад основного матеріалу дослідження. Сьогодні формування критичного мислення набуває особливої актуальності і важливості, оскільки соціальний та технічний прогрес висуває до особистості вимогу вміти швидко адаптуватися до сучасних умов функціонування суспільства, бути здатною до змін і самовдосконалення, знаходити шляхи розв'язання соціальних і професійних завдань у нетипових ситуаціях. Інтенсивні процеси глобалізації й інформатизації вимагають від сучасного студента ЗВО абсолютно нового типу мислення, яким, як ми вважаємо, іє критичне мислення.

Цінність критичного мислення набуває високого пріоритету і визначає цілі розвитку сучасної вітчизняної системи вищої освіти. Водночас реальний стан розвитку критичного мислення в студентів вітчизняних ЗВО залишається суперечливими. За результатами дослідження Л. Ткаченко (Ткаченко, 2015 ) встановлено, що показники рівня сформованості критичного мислення в студентів ЗВО знаходяться на низькому рівні, вони представлені переважно низьким (50 \%) та середнім рівнями (близько $40 \%$ ), високий рівень за показниками вказаних критеріїв знаходиться у межах 10 \% (Ткаченко, 2015). У 2018/2019 навчальному році ми провели зріз рівня сформованості критичного мислення в студентів Національного університету «Чернігівський колегіум» імені Т. Г. Шевченка. У зрізі взяло участь 82 студенти освітньо-кваліфікаційного рівня «бакалавр» 1, 2, 3 та 4 курсів денної форми навчання. Для об'єктивного результату репрезентативність студентів за курсами була приблизна однакова. Результати зрізу засвідчили, що більшість студентів 92,7 \% (76 студентів) перебуває на середньому рівні на його нижній межі; 4,9 \% (4 студенти) мають низький розвиток і лише 2,4 \% (2 студенти) показали високий рівень розвитку критичного мислення. Жодного студента, який набрав необхідну кількість балів відповідно до норм дуже високого рівня критичного мислення, не виявилося, середній показник розвитку критичного мислення становив 14,6 (Конотоп, 2019 с. 99).

Визначають, що навички критичного мислення спостерігаються в студентів зазвичай ситуативно i не мають системності: більшість молодих людей не можуть пояснити, чому в одних випадках їм вдається критично осмислити певне явище, а в інших вони сприймають факти в готовому вигляді, не піддаючи їх критичному аналізу; не усвідомлюють сутності критичного мислення та механізму його здійснення; термін «критичне мислення» переважно асоціюється в них із критикою, що спрямована на знаходження негативних аспектів певних явищ та засудження того, що не відповідає прийнятим у певному середовищі поглядам (Ткаченко, 2015).

Дослідники в різних галузях (Ф. І. Гиренок, Г. М. Гич, С. В. Докука, В. Курбатов, М. Маклюен, С. Сімакова, Т. В. Семеновських, Е. Тоффлер та ін.), відзначають таке явище, як «кліпове» мислення (в англомовній літературі використовується термін «netthinking», тобто net-мислення). Термін «кліпове мислення» походить від англійського «а clip», що означає уривок, наприклад, фрагмент фільму, тексту або вирізки із журналу/газети. Як на причину виникнення феномену кліпове мислення науковці вказують, що «внаслідок експоненціального зростання кількості інформації людям доводиться трансформувати свої когнітивні стратегії та встигати опрацьовувати більше повідомлень за менший проміжок часу, що призвело до виникнення поняття «кліпового» мислення» (Докука, 2013, с. 175).

В умовах становлення кіберсуспільства та стрімкого розвитку основних засобів комунікації в ньому змінюється культура сприйняття інформації. Світ цифрових технологій стає визначальними у формуванні психофізіологічних особливостей сучасного студента, однією із яких є поява кліпового мислення, що передбачає не вміння зосереджуватися на конкретному об'єкті, а фрагментарність відображення інформаційного потоку з високою швидкістю перемикання фрагментів інформації, без урахування зв'язків між ними, непослідовність сприйняття інформації, відсутність цілісного сприйняття змісту інформації та його рефлексивного засвоєння. Проте його перевагою є велика швидкість опрацювання інформації, динамізм у пізнавальній діяльності.

За таких умов, на нашу думку, під час освітнього процесу, по-перше, педагоги повинні враховувати обидва типи мислення - кліпове та стратегічне i підтримувати баланс між ними; по-друге, дослідити 
ефективне співвідношення між цими видами мислення, ураховуючи різні організаційні форми навчання - лекційні, практичні заняття та самостійну роботу студентів; по-третє, важливим є визначення певної ієрархії стратегій, які допоможуть активізувати ці типи мислення, по-четверте, підібрати необхідні засоби для такого навчання (Конотоп, 2020, с. 382).

Ефективним засобом формування критичного мислення можуть стати МВОК (англійською мовою MOOC-massive (масовий, великий) open (відкритий, безкоштовний) online (онлайн) course (курс), тобто відкрита платформа, яка за сприяння визнаного фахівця в певній галузі інтегрує в собі не лише вільно доступні інтернет-ресурси, а й соціальні мережі, а також пропонує майданчик для активного спілкування великого числа студентів, які самоорганізовують свою участь відповідно до власних цілей навчання та набутих знань і навичок (McAuley, B. Stewart, 2010).

За прогнозами дослідників, аудиторія МВОК, яка залучена до освітнього процесу, зросте з 150 млн у 2009 році до 250 млн в 2025 році (MOOCs4D). Аналізуючи МВОК, Т. М. Хусяінов виокремлює їхні основні характеристики, які відрізняють їх від традиційної освіти: лаконічна подача матеріалу — короткі відеоролики охоплюють одну тему або окрему частину теми; перевірка знань - переважно тестування, але $€$ і досвід виконання завдань, здійснене технологією взаємної перевірки студентів: кожен студент перевіряє три чужі роботи, натомість його роботу перевіряють три інших студенти; залучення викладачів найкращих (американських, європейських, російських) університетів; наявність чітких графіків, розкладу, дедлайнів, за дотриманням яких стежить автоматизована система платформи МВОК; наявність численних каналів зворотного зв'язку студент/слухач - викладач; безкоштовність або умовна безкоштовність - оплата за отримання підтвердженого сертифіката про закінчення курсу; масовість і глобальність - десятки тисяч слухачів з усього світу; після успішного закінчення курсу користувач отримує можливість завантажити іменний сертифікат про проходження певного курсу, із зазначенням прізвища викладача i 3ВО, у якому він працює (Хусяінов 2015, с. 3).

Дафна Колер визначає такі позитивні риси МВОК: знання і освіту, які раніше були доступні лише малій кількості людей, зараз відкрилися практично всім, у кого є комп'ютер і Інтернет (курси безкоштовні); студенти інтегруються і кооперуються не лише офлайн, але й онлайн; оскількм кількість студентів велика, студенти самі перевіряють завдання один одного, якщо йдеться про складні перевірки, як, наприклад, оцінка есе або інших творчих завдань; така система освіти (mastery learning) набагато ефективніша від класичної і стає ближчою до ефективності навчання один на один (індивідуальне отримання знань: один студент - один викладач). Якщо розглянути розподіл студентів за класичного лекційного навчання, то успішно засвоять матеріал приблизно 50 \%, тоді як за навчання один на один успішно засвоять приблизно 98 \% студентів. Наразі основна проблематика онлайнкурсів, на думку Дафни Колер, - це розв'язати задачу «двох сигм» - тобто наблизити ефективність онлайн-освіти до утворення «один на один» шляхом «роби Лернінг» і персоналізації навчання (Дафна Колер).

Використання МВОК має й певні недоліки. P. А. Дорофєєв називає такі проблеми, що виникають під час роботи з МВОК: недовіра до знань, які отримані онлайн; МВОК не розвивають практичних умінь; відсутність систематизації і стандартів опису онлайн курсів (Дорофєєв).

Розглянемо курси 3 критичного мислення, які пропонують провідні освітні МВОК-платформами.

\section{«Освітні інструменти критичного мислення"}

МВОК-платформа: Prometheus

Назва курсу: «Освітні інструменти критичного Мета курсу: $\quad$ мислення» ного мислення освітян, рефлексії освітньої діяльності

Автори: доктор педагогічних наук, професор С. Терно

Мова: українська

Курс започатковано: 28.11. 2018 р.

Обсяг курсу: $\quad 60$ годин

Сертифікат: надається

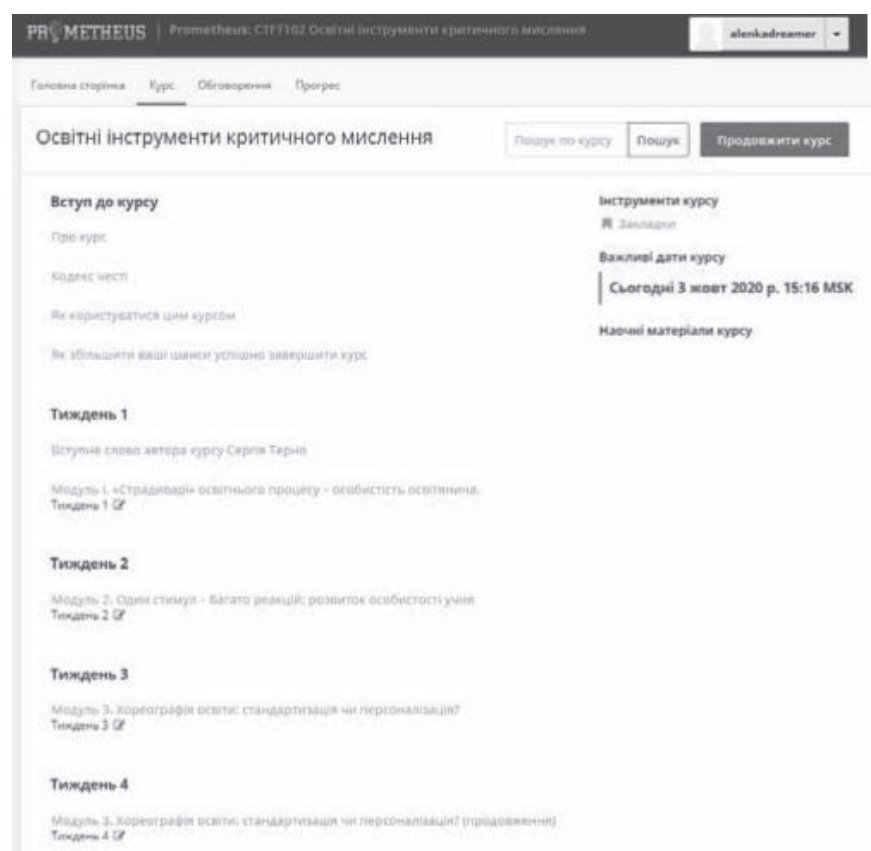

Рис. 1. Фрагмент сторінки МВОК «Освітні інструменти критичного мислення» 


\section{«Критичне мислення для освітян»}

МВОК-платформа:

Назва курсу:

Мета курсу:

Автори:

Мова:

Prometheus

«Критичне мислення для освітян» навчити користувачів стратегій критичного мислення

доктор педагогічних наук, професор С. Терно; кандидат філософських наук, доцент Н. Степанова; директор СШ № 148 ім. Івана Багряного м. Києва С. Горбачов. українська

Курс започатковано: 30.10.2017 p.

Обсяг курсу: $\quad 30$ годин

Сертифікат: надається

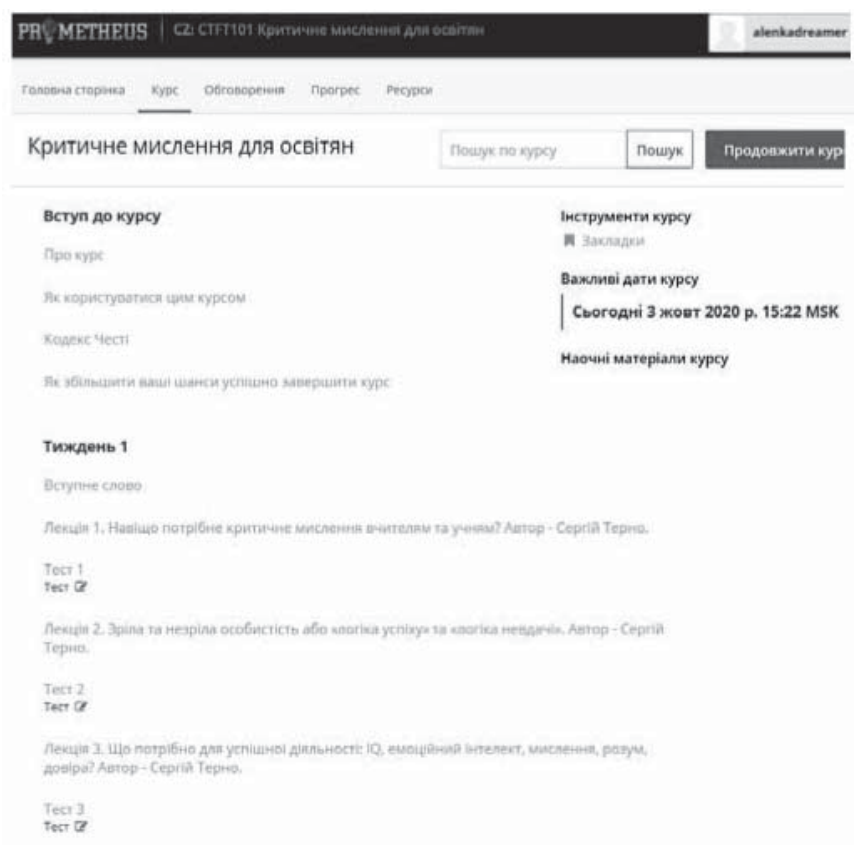

Рис. 2. Фрагмент сторінки МВОК «Критичне мислення для освітян»

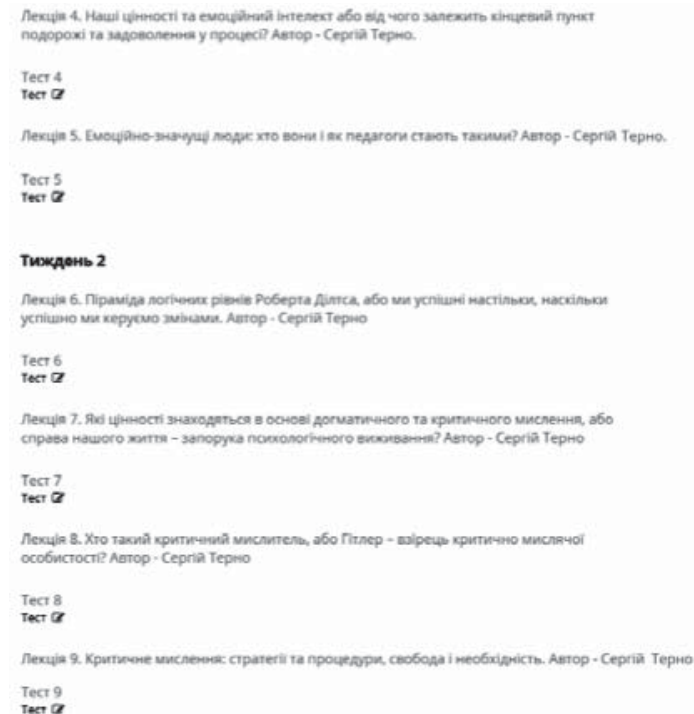

Рис. 3. Фрагмент сторінки МВОК «Критичне мислення для освітян»

\section{«Наука повсякденного мислення»}

МВОК-платформа: Prometheus

Назва курсу:

Мета курсу:

«Наука повсякденного мислення» допомогти освітянам зрозуміти психологію мислення, сформувати навички та вміння для розвитку пам'яті та ознайомитись із новітніми навчальними технологіями провідних американських фахівців.

Автори: старший викладач у сфері когнітивістики Джейсон Танген; дослідник природи візуальної експертизи в галузі медицини і судової медицини Метью Томпсон; продюсер курсу «Наука повсякденного мислення» Емма МакКензі.

Мова: у українська

Курс започатковано: 28.11. 2018 р.

Обсяг курсу: $\quad 80$ годин

Сертифікат: надається

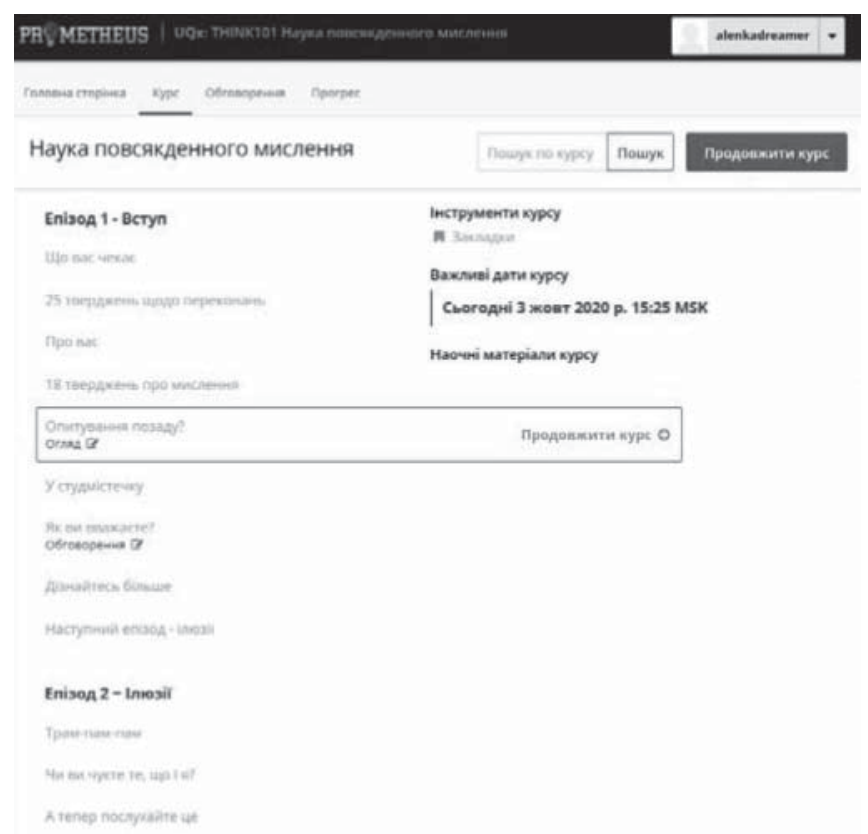

Рис. 4. Фрагмент сторінки МВОК «Наука повсякденного мислення»

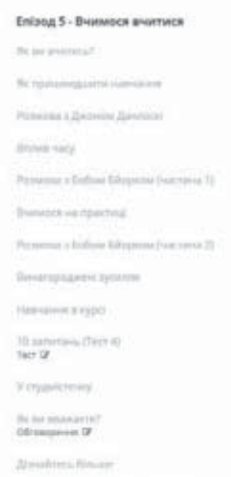

Рис. 5. Фрагмент сторінки МВОК «Наука повсякденного мислення» 


\section{«Вступ до критичного мислення»}

МВОК-платформа: Назва курсу: Мета курсу:

BУMonline

«Вступ до критичного мислення» формування здорового способу мислення та імунітету від зловмисних маніпуляцій

Автори: психотерапевт, військовий психолог, Олексій Карачинський

Мова: російська

Курс започатковано: 01.09.2016 p.

Обсяг курсу: 15 занять

Сертифікат: немає інформації

\begin{tabular}{|c|c|}
\hline Частина 1 & o. Bctynnewate. \\
\hline Частина 2 & 1 3акон тошрества. \\
\hline Частина 3 & 2.3 Закон непропиворечия \\
\hline Частина 4 & 3 Закон ислиоченного третието. \\
\hline Частина 5 & 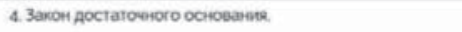 \\
\hline Частина 6 & 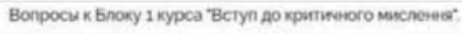 \\
\hline Блок & Muwnerse. \\
\hline Частина 1 & 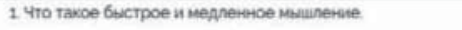 \\
\hline Частина 2 & 21 Зиристическан поднена вопроса. \\
\hline Частина 3 & 22 Heocosiannoe mieunerave. \\
\hline Чәстина 4 & 23 Зеристика доступносте. \\
\hline Частина 5 & 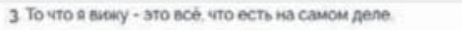 \\
\hline Частина 6 & 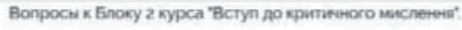 \\
\hline Enok & 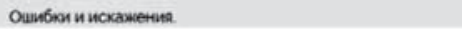 \\
\hline
\end{tabular}

Рис. 6. Фрагмент сторінки МВОК «Стратегічне мислення»

МВОК-платформа:

Назва курсу:

Мета курсу:

Автор:

Мова:

BYMonline

«Стратегічне мислення»

навчити користувачів мислити стратегічно

кандидат технічних наук, декан Київської бізнес-школи М. Крикунов російська

Курс започатковано: 01.07.2016 p.

Обсяг курсу: 29 занять

Сертифікат: немає інформації

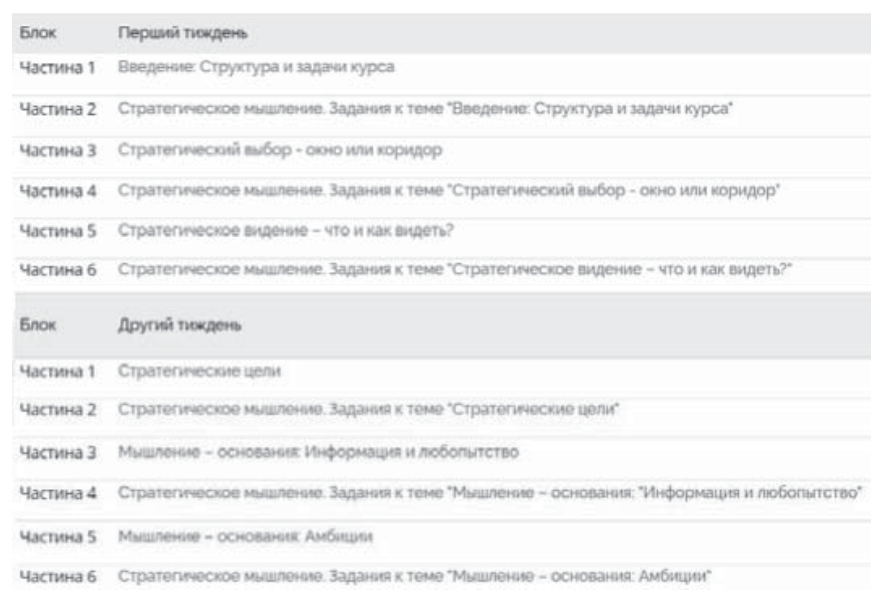

Рис. 7. Фрагмент сторінки МВОК

«Стратегічне мислення»

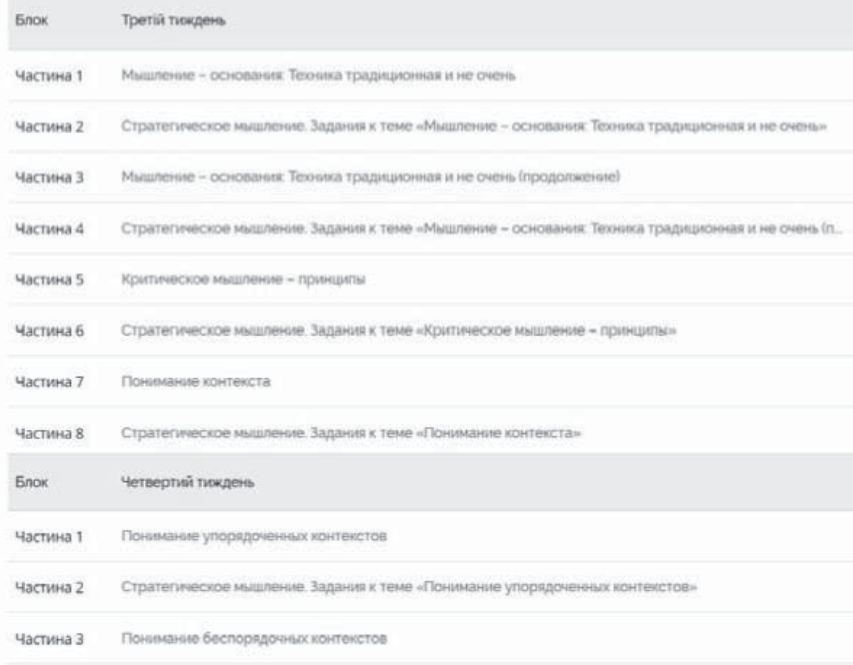

Рис. 8. Фрагмент сторінки МВОК «Стратегічне мислення»

\section{"Ключові вміння 21-го століття"}

МВОК-платформа: courses.ed-era

Назва курсу: 《Ключові вміння 21-го століття»

Мета курсу: ознайомити користувачів 3 ключовими вміннями 21-го століття

Автори: кандидат філологічних наук Катерина Худик; учитель-методист Андрій Вербовий.

Мова: у українська

Курс започатковано: травень 2020 р.

Обсяг курсу: 2 модулі

Сертифікат: надається

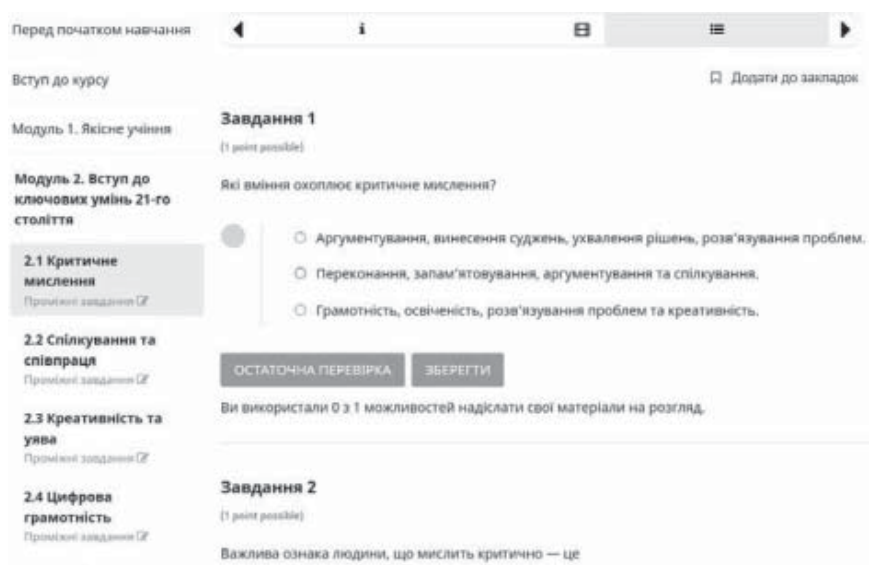

Рис. 9. Фрагмент сторінки МВОК «Ключові вміння 21-го століття»

\section{«Бери і роби»}

МВОК-платформа: Назва курсу: Мета курсу:

Courses.ed-era «Бери і роби» надати практичні інструменти для вчителів: стратегії критичного мислення, корисні інструменти для креативного аналізу та ін. 
Автори: $\quad 15$ експертів ГС “Освіторія” (нейропсихологи, поведінкові спеціалісти та інші спеціалісти, що спеціалізуються на методиках змішаного навчання, креативного мислення, формувального оцінювання та нейрофізіологіі).

Мова: українська

Курс започатковано: жовтень 2019 р.

Обсяг курсу: 15 занять

Сертифікат: надається
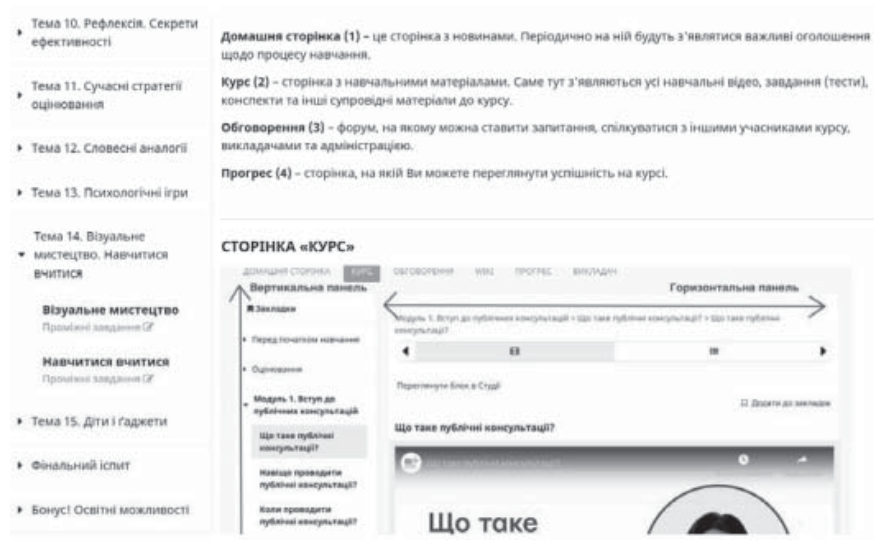

Рис. 10. Фрагмент сторінки МВОК

«Бери і роби»

\section{«Critical Thinking»}

МВОК-платформа: khanacademy

Назва курсу:

Мета курсу:

\section{«Critical Thinking»}

сформувати у користувачів навички мислити чітко та самостійно, висловлювати обгрунтовані аргументи, виявляти суперечності в міркуваннях, розуміти логічний зв'язок між ідеями, а також будувати та оцінювати аргументи.

Автори: khanacademy

Мова: англійська

Курс започатковано: Обсяг курсу: немає інформації

Сертифікат:

34 заняття

немає
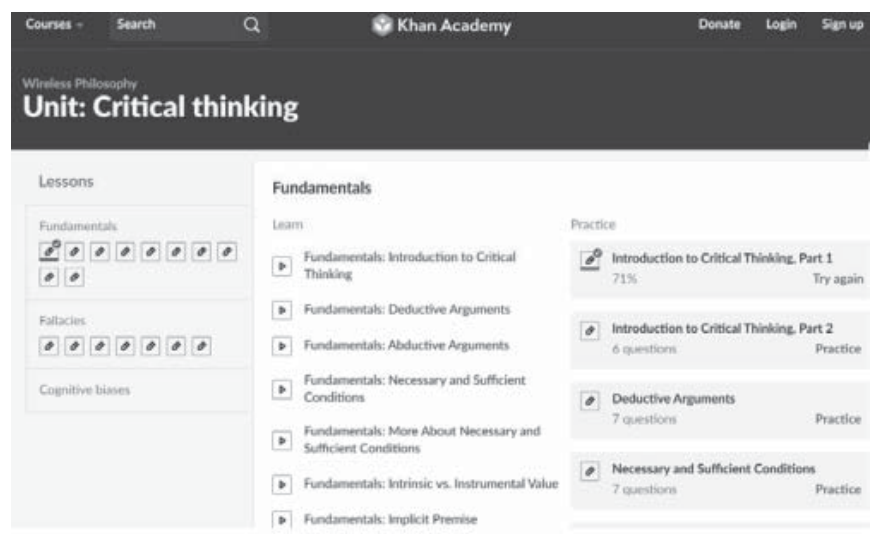

Рис. 11. Фрагмент сторінки МВОК «Critical Thinking»
Результати дослідження. Викладане вище зумовлює актуальність забезпечення розвитку критичного мислення в студентів вітчизняних 3ВО, адже результати досліджень науковців та власні спостереження за освітнім процесом у ЗВО засвідчують необхідність спеціально організованої діяльності з формування критичного мислення сучасного студента. Застосування технології критичного мислення $є$ вкрай важливим у сучасному освітньому процесі, оскільки змушує викладачів переорієнтовутися із традиційної парадигми навчання, яка була спрямована на переважно механічне запам'ятовування і відтворення вивченого матеріалу до навчання, метою якого є самостійне і свідоме мислення студентів, тим самими готуючи молодь до сучасного життя у швидкозмінному інформаціному середовищі і водночас даючи великий поштовх для майбутнього фахівця до навчання упродовж усього подальшого життя. Навчання IM має великий потенціал для розвитку стратегій критичного мислення, які дають змогу ефективно генерувати нові ідеї, індивідуалізувати навчання, стимулювати іншомовне мовлення студентів, формувати навички самооцінки та взаємооцінки, рефлексії.

Перспективи подальших наукових розвідок. Наступні кроки полягають у дослідженні методики формування і розвитку критичного мислення в студентів ЗВО та на його основі формування іншомовної НСтК.

\section{СПИСОК ПОСИЛАНЬ}

Дафна, Коллер (2009). С мира по курсу. Взято з: http:// digitaloctober.ru/player/content/71.

Докука, С.В. (2013). Клиповое мышление как феномен информационного общества. Общественные науки и современность. М., № 2. С. 169-176.

Дорофеев, Р. А. (2008). Будущее высшего образования. Взято 3: http://habrahabr.ru/post/181267.

Зінченко, А.Г., Саприкіна, М.А. (2016). Навички для України 2030: погляд бізнесу. К.: ТОВ «Видавництво «ЮСТОН», 2016.

Конотоп, О. С. (2019). Результати зрізу рівня сформованості критичного мислення у студентів закладів вищої освіти. Вісник Національного університету «Чернігівський колегіум» імені Т. Г. Шевченка. Випуск 5 (161). Серія Педагогічні науки. Чернігів, С. 97-100.

Конотоп, О. С. (2020). Стратегічне мислення VS кліпове мислення у практичній іншомовній підготовці студентів немовних закладів вищої освіти. Актуальні проблеми формування творчої особистості педагога в контексті наступності дошкільної та початкової освіти : збірник матеріалів II Міжнародної науково-практичної Інтернет-конференції (Вінниця, ВДПУ імені Михайла Коцюбинського, 3 березня 2020 р.) / за ред. О. А. Голюк ; Вінницький державний педагогічний університет імені Михайла Коцюбинського, факультет дошкільної, початкової освіти та мистецтв імені Валентини Волошиної. Вінниця: ТОВ «Меркьюрі-Поділля», Вип. 9. С. 380-382. 
Конотоп, О. С. (2020). Стратегічне мислення як основа формування іншомовної навчально-стратегічної компетентності у студентів немовних закладів вищої освіти. Актуальні питання теорії та практики в галузі права, освіти, соціальних та поведінкових наук - 2020: матеріали міжнар. наук.-практ. конф. (м. Чернігів, 23-24 квіт. 2020 р.): у двох томах. Т. 2 /гол. ред. О. М. Тогочинський. Академія Державної пенітенціарної служби. Чернігів: Академія ДПтС, С. 343-346.

Терно, С. (2009). Критичне мислення - сучасний вимір суспільнознавчої освіти. Запоріжжя: Просвіта.

Ткаченко, Л.І. (2015). Формування критичного мислення у майбутніх учителів початкової школи у процесі професійної підготовки. (Дис. канд. пед. наук). Інститут педагогічної освіти і освіти дорослих НАПН України, Київ.

Хусяинов, Т. М. (2015). Основные характеристики массовых открытых онлайнкурсов (МООС) как образовательной технологии. Наука. Мысль: электронный периодический журнал. № 2. С.1-7.

A. McAuley, B. Stewart, G. Siemens, and D. Cormier, The MOOC Model for Digital Practice. Created through funding received by the University of Prince Edward Island through the Social Sciences and Humanities Research Councilıs "Knowledge Synthesis Grants on the Digital Economy", 2010.

Jobs in 2030: What skills will you need? Retrieved from: https:// www.nesta.org.uk/blog/jobs-in-2030-what-skills-will-youneed/? cf chl captcha tk $=5 \mathrm{a} 3 \mathrm{e} 6 \mathrm{a} 3 \mathrm{cfd} 5 \mathrm{c} 290169 \mathrm{bb} 1$ c0a08c431216d41acf8-1575409202-0-ATDXR0txniw8ygQ IX95PEcNhr7vh-dlq8kNO05yKGj7GoYPrtB905Y4MC82od379aelN7alQprZRZOb59ZMGsbRaOM5gPcPz9f2_UTvKE4wsi9Xh7b2dq8MTvjlc2bZYAii17HKRmPb3v34Ey56KmbXRS9tOiOZ_AsIGdtrbcSqy1XNMrT1ml_yliJ1AAxbzzBbJ31Q4Ir R69-kXP0HDrKCupHCEFKWyHW8o22YvcIM Y_3UGJ3RuU62v16eFIR1rAeTMhQMq22AWiXIJAVfPe21 ISUFUluREV7ovggPI7tPMSJI9KiPAA6c-QIZD

MOOCs4D: Potential at the Bottom of the Pyramid. Conference Report. April 10-11.2014. Retrieved from: http: //iite.unesco. org/files/news/639173/MOOCs4D_ConfReport_July2014. pdf

The Partnership for 21st Century Learning (P21). Retrieved from: http://www.p21.org

\section{REFERENCES}

Dafna, Koller (2009). S myra po kursu. Vzyato z: http://digitaloctober.ru/player/content/71.

Dokuka, S. V. (2013). Klypovoe myshlenye kak fenomen ynformatsyonnoho obshchestva. Obshchestvennye nauky $y$ sovremennost'. M., № 2. S. 169-176.

Dorofeev, R. A. (2008). Budushchee vyssheho obrazovanyya. Vzyato z: http://habrahabr.ru/post/181267.

Zinchenko, A.H., Saprykina, M.A. (2016). Navychky dlya Ukrayiny 2030: pohlyad biznesu. K.: TOV «Vydavnytstvo "YUSTON», 2016.

Konotop, O. S. (2019). Rezul'taty zrizu rivnya sformovanosti krytychnoho myslennya u studentiv zakladiv vyshchoyi osvity. Visnyk Natsional'noho universytetu «Chernihivs'kyy kolehium» imeni T.H. Shevchenka. Vypusk 5 (161). Seriya Pedahohichni nauky. Chernihiv, S. 97-100.

Konotop, O. S. (2020). Stratehichne myslennya VS klipove myslennya u praktychniy inshomovniy pidhotovtsi studentiv nemovnykh zakladiv vyshchoyi osvity. Aktual'ni problemy formuvannya tvorchoyi osobystosti pedahoha $\mathrm{v}$ konteksti nastupnosti doshkil'noyi ta pochatkovoyi osvity : zbirnyk materialiv II Mizhnarodnoyi naukovo-praktychnoyi Internet-konferentsiyi (Vinnytsya, VDPU imeni Mykhayla Kotsyubyns'koho, 3 bereznya 2020 r.) / za red. O.A. Holyuk; Vinnyts'kyy derzhavnyy pedahohichnyy universytet imeni Mykhayla Kotsyubyns'koho, fakul'tet doshkil'noyi, pochatkovoyi osvity ta mystetstv imeni Valentyny Voloshynoyi. Vinnytsya: TOV «Merk'yuri-Podillya», Vyp. 9. S. 380-382.

Konotop, O. S. (2020). Stratehichne myslennya yak osnova formuvannya inshomovnoyi navchal'no-stratehichnoyi kompetentnosti u studentiv nemovnykh zakladiv vyshchoyi osvity. Aktual'ni pytannya teoriyi ta praktyky v haluzi prava, osvity, sotsial'nykh ta povedinkovykh nauk - 2020: materialy mizhnar. nauk.-prakt. konf. (m. Chernihiv, 23-24 kvit. 2020 r.): u dvokh tomakh. T. 2 /hol. red.: O. M. Tohochyns'kyy. Akademiya Derzhavnoyi penitentsiarnoyi sluzhby. Chernihiv: Akademiya DPtS, S. 343-346. 8.

Terno, S. (2009). Krytychne myslennya - suchasnyy vymir suspil'noznavchoyi osvity. Zaporizhzhya: Prosvita.

Tkachenko, L. I. (2015). Formuvannya krytychnoho myslennya u maybutnikh uchyteliv pochatkovoyi shkoly u protsesi profesiynoyi pidhotovky. (Dys. kand. ped. nauk). Instytut pedahohichnoyi osvity i osvity doroslykh NAPN Ukrayiny, Kyyiv.

Khusyaynov, T. M. (2015). Osnovnye kharakterystyky massovykh otkrytykh onlaynkursov (MOOC) kak obrazovatel'noy tekhnolohyy. Nauka. Mysl': élektronnyy peryodycheskyy zhurnal. № 2. S.1-7.

A. McAuley, B. Stewart, G. Siemens, and D. Cormier, The MOOC Model for Digital Practice. Created through funding received by the University of Prince Edward Island through the Social Sciences and Humanities Research Council's "Knowledge Synthesis Grants on the Digital Economy", 2010.

Jobs in 2030: What skills will you need? Retrieved from: https:// www.nesta.org.uk/blog/jobs-in-2030-what-skills-will-youneed/? ?cf_chl_captcha_tk_=5a3e6a3cfd5c290169bb1 c0a08c431216d41acf8-1575409202-0-ATDXR0txniw8ygQ IX95PEcNhr7vh-dlq8kNO05yKGj7GoYPrtB905Y4MC82od379aeIN7alQprZRZOb59ZMGsbRaOM5gPcPz9f2_UTvKE4wsi9Xh7b2dq8MTvjlc2bZYAii17HKRmPb3v34Ey56KmbXRS9tOiOZ AsIGdtrbcSqy1XNMrT1ml yliJ1AAxbzzBbJ31Q4Ir_R69-kXP0HDrKCupHCEFKWyHW8o22YvcIM Y 3UGJ3RuU62v16eFIR1rAeTMhQMq22AWiXIJAVfPe21 ISUFUluREV7ovggPI7tPMSJI9KiPAA6c-QIZD

MOOCs4D: Potential at the Bottom of the Pyramid. Conference Report. April 10-11.2014. Retrieved from: http: //iite.unesco. org/files/news/639173/MOOCs4D_ConfReport_July2014. pdf

The Partnership for 21st Century Learning (P21). Retrieved from: http://www.p21.org 